\title{
Indicators Engineering for Land Uptake and Agricultural Loss. A Study in European Countries
}

\author{
Francesco Zullo*, Cristina Montaldi, Bernardino Romano \\ Department of Civil, Construction-Architectural and Environmental Engineering, University of L'Aquila, L'Aquila (AQ), \\ Italy \\ Email: ^francesco.zullo@univaq.it, cristina.montaldi@graduate.univaq.it, bernardino.romano@univaq.it
}

How to cite this paper: Zullo, F., Montaldi, C., \& Romano, B. (2021). Indicators Engineering for Land Uptake and Agricultural Loss. A Study in European Countries. Current Urban Studies, 9, 813-830. https://doi.org/10.4236/cus.2021.94048

Received: November 2, 2021

Accepted: December 28, 2021

Published: December 31, 2021

Copyright $\odot 2021$ by author(s) and Scientific Research Publishing Inc. This work is licensed under the Creative Commons Attribution International License (CC BY 4.0).

http://creativecommons.org/licenses/by/4.0/ (c) (i) Open Access

\begin{abstract}
Soil and its associated ecosystem services are indispensable resources for human survival on the planet. Current models of economic and social development exert unprecedented pressures and demands on the land, creating an unsustainable imbalance. The objective of this work is to assess the land use changes that have occurred in EU countries from 1990 to 2018 through CORINE Land Cover. Particular attention has been paid to the urban conversion of soils to agricultural use, as primary production represents one of the most tangible ecosystem services provided by soils, the quantification of which is complex due to the synergistic effect between them. The study has analyzed and evaluated the agricultural losses resulting from urbanization for all EU countries and produced an economic estimate of these losses. The results show that the prevailing transformations are those of anthropogenic origin and in particular urbanization at the expense of agricultural areas, although with different drive forces in the various countries. The importance of knowing the extent of this phenomenon lies in the possibility of implementing targeted corrective actions aimed at limiting, mitigating and compensating the effects of anthropogenic soil transformations.
\end{abstract}

\section{Keywords}

Land Uptake, Agricultural Loss, Urban Areas, Indicators Engineering

\section{Introduction}

Soil is an extremely important resource that is not rapidly renewable and is vital for our health and the economy, as well as for the production of food and new 
medicines (Foley et al., 2005; European Commission, 2020). Sustainable land use is the foundation of all UN Sustainable Development Goals (SDGs). Indeed, in order to achieve the 17 SDGs, including those of the social and economic nature, intact soils capable of delivering essential ecosystem services are indispensable (Folke et al., 2016). As highlighted by the European Commission in the EU Biodiversity Strategy 2030: "in the EU, the degradation of soil is having considerable environmental and economic consequences. Poor land management, such as deforestation, overgrazing, unsustainable farming and forestry practices, construction activities and land sealing are among the main causes of this situation.” Therefore, soils must be managed in a way that preserves their potential to provide goods and services. These services are lost or weakened due to the pressure generated by certain factors such as the climate crisis, water pollution, atmospheric pollution (Agrawal, 2005; Emberson et al., 2003; Ruddock \& Lopes, 2006) and soil pollution (Ashraf et al., 2010; Levers et al., 2018; Falcucci et al., 2007), the abandonment of the countryside and urban conversion is defined as "the total or partial replacement of the land cover with consequent loss of the original function" (Prokop et al, 2011; EEA, 2017; Munafò, 2021). This study identifies prevailing landscapes and land use transformations in order to investigate the phenomenon of urban land conversion at both European and national scales. Specifically, two macro-types of landscape-environmental mosaics have been identified: the first includes areas with a predominantly anthropogenic physiognomy that tend to be more "managed", while the second includes areas of greater environmental or transition quality and much less regulated by planning forms. The areal changes that have occurred over time are not always been regulated. In some cases which are spontaneous and influenced by the market, economic crises and local or global events without specific control (Zanfi, 2013; Romano et al., 2018). The diachronic assessment of urban soil conversion has made it possible to estimate, also in economic terms, the loss of one of the main ecosystem services: agricultural production. Estimating the loss of ecosystem services in quantitative terms, even more so in economic terms, is a complex task; one of the reasons is the synergistic effect between them. Taking this into account, the study produced an assessment of the equivalent agricultural loss in Europe between 1990 and 2018. The results made it possible not only to identify the extent of the phenomenon but also to take appropriate measures aimed at mitigating the effects of anthropogenic soil transformations.

\section{Materials and Methods}

The study analyzed the territories of the United Kingdom and the EU Member States minus the countries of Malta, Luxembourg and Cyprus. Specifically, the analysis covered, as shown in Figure 1, the European continental areas and in the case of island states only the major ones. Starting from the 44 land cover categories defined by the European classification proposed in the Corine Land Cover (CLC) (Büttner, 2014; Bossard et al., 2000), excluding maritime environments, six 


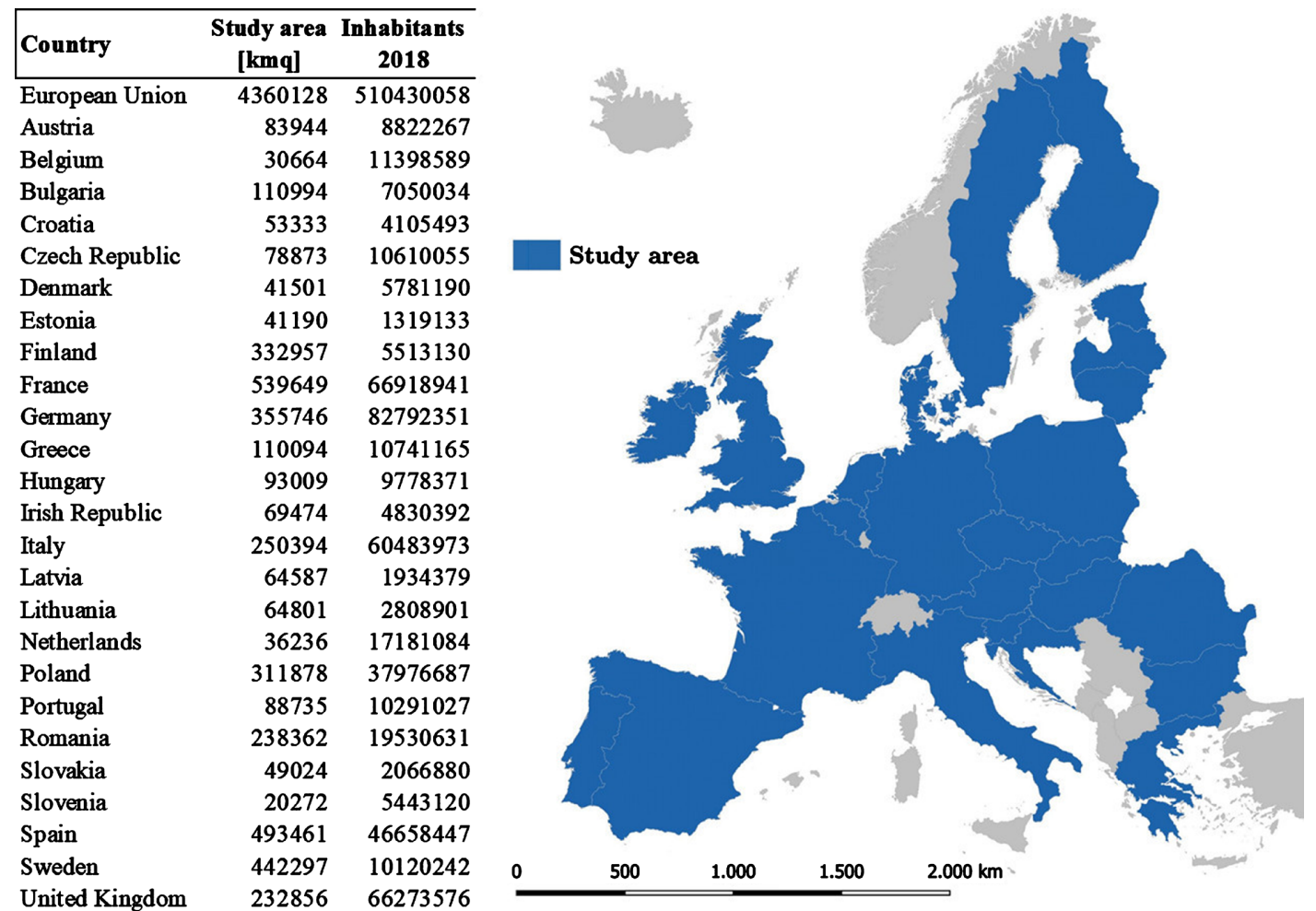

Figure 1. Study area and demographic characteristics.

European Landscape Macrosystems (ELM) consisting of artificial areas covered by urbanisation (U), intensive agriculture (IA), extensive agriculture (EA), forests (F), natural and semi-natural areas (SN) and water bodies (W) were extracted. In most cases the assignment is quite automatic, while some clarifications must be made for the inclusion of CLC categories "221", "222", "223" in the ELM "IA" or "EA". These types of land use have different connotations, however for the first two AIs prevail, while EAs predominate for the last one. The ELM mosaics (Table 1) were then grouped into two macrosystems: $\operatorname{ELM}^{\wedge}=(U+I A+E A)$ and $E^{\prime} M^{*}$ $=(\mathrm{F}+\mathrm{SN}+\mathrm{W})$ with $\mathrm{ELM}^{\wedge}$ comprising mosaics with predominantly terrestrial artificialization and $\mathrm{ELM}^{\star}$ those with the most important areas in terms of ecological-environmental quality and connection between ecosystems. It is useful to recall that urbanised areas are defined as those intended for urban functions, replacing or maintaining natural soil. They therefore include built-up land and land used for ancillary functions of the settlement, such as public and private gardens, sports facilities, dirt roads and other service areas, excluding the suburban road network.

Data comes from several sources. Those relating to territorial units (NUTS: Nomenclature des Unités Territoriales Statistiques) and demographic data come from the portal of the Statistical Office of the European Union

(https://ec.europa.eu/eurostat/, 2020). The geographical dataset of the territorial units is at a scale of 1:1M. This dataset is mainly derived from EuroBoundary Map v 2020 (Eurogeographics, Reference Date 2018.12.31) and was obtained by 
Table 1. Cluster of ELM systems obtained from CLC categories.

\begin{tabular}{|c|c|c|c|}
\hline $\begin{array}{c}\text { ELM } \\
\text { macrosystem }\end{array}$ & ELM system & CLC code & CLC categories \\
\hline & & 111 & Continuous urban fabric \\
\hline & & 112 & Discontinuous urban fabric \\
\hline & & 121 & Industrial or commercial units \\
\hline & & 122 & Road and rail networks and associated land \\
\hline & & 123 & Port areas \\
\hline & $\mathrm{U}$ & 124 & Airports \\
\hline & & 131 & Mineral extraction sites \\
\hline & & 132 & Dump sites \\
\hline & & 133 & Construction sites \\
\hline & & 141 & Green urban areas \\
\hline & & 142 & Sport and leisure facilities \\
\hline \multirow[t]{21}{*}{$\mathrm{ELM}^{\wedge}$} & & 211 & Non-irrigated arable land \\
\hline & & 212 & Permanently irrigated land \\
\hline & IA & 213 & Rice fields \\
\hline & & 221 & Vineyards \\
\hline & & 222 & Fruit trees and berry plantations \\
\hline & & 223 & Olive groves \\
\hline & & 231 & Pastures \\
\hline & & 241 & Annual crops associated with permanent crops \\
\hline & EA & 242 & Complex cultivation patterns \\
\hline & & 243 & $\begin{array}{l}\text { Land principally occupied by agriculture, } \\
\text { with significant areas of natural vegetation }\end{array}$ \\
\hline & & 244 & Agro-forestry areas \\
\hline & & 311 & Broad-leaved forest \\
\hline & $\mathrm{F}$ & 312 & Coniferous forest \\
\hline & & 313 & Mixed forest \\
\hline & & 321 & Natural grasslands \\
\hline & & 322 & Moors and heathland \\
\hline & & 323 & Sclerophyllous vegetation \\
\hline & & 324 & Transitional woodland-shrub \\
\hline & $\mathrm{SN}$ & 331 & Beaches, dunes, sands \\
\hline & & 332 & Bare rocks \\
\hline & & 333 & Sparsely vegetated areas \\
\hline \multirow[t]{11}{*}{$\mathrm{ELM}^{*}$} & & 334 & Burnt areas \\
\hline & & 335 & Glaciers and perpetual snow \\
\hline & & 411 & Inland marshes \\
\hline & & 412 & Peat bogs \\
\hline & & 421 & Salt marshes \\
\hline & & 422 & Salines \\
\hline & $\mathrm{W}$ & 423 & Intertidal flats \\
\hline & & 511 & Water courses \\
\hline & & 512 & Water bodies \\
\hline & & 521 & Coastal lagoons \\
\hline & & 522 & Estuaries \\
\hline
\end{tabular}


generalisation of the 1:100K scale. Land cover data is derived from Corine Land Cover (CLC), a project that began in 1985 (base year 1990) with updates produced in 2000, 2006, 2012 and 2018. The dataset, from the Copernicus project portal (https://land.copernicus.eu/pan-european/corine-land-cover, 2020), is based on the classification of land cover/land use from satellite imagery through semi-automatic procedures. The standard division into 44 classes is divided into 3 levels. Minimum Mapping Unit (MMU) is 25 ha for areal phenomena and $100 \mathrm{~m}$ for linear phenomena (MMW). The time series is completed by change layers (CHA) with MMU 5 ha. Data for agricultural loss assessments such as national wheat yields between 1990 and 2018, national annual wheat production and import data for the year 2018, come from the Food and Agriculture Organization (FAO) of the United Nations portal, http://www.fao.org/faostat/en/\#data/QC). Agricultural yields, expressed per hectare (ha), are values calculated by noting the annual production (tonnes/year) of dry cereals and the area actually harvested. National selling prices for wheat (absolute prices expressed in $€ / 100 \mathrm{~kg}$ of harvest) were found on the Eurostat website in the agriculture section, minus the figure for France and Ireland. For the latter, this information comes from the FAO portal. The time reference for all statistics is a calendar year.

Given the plurality of variables and the extent of the data to be processed, a set of indices was structured to allow rationalisation of the information and a clear and effective view of the phenomena studied. The definitions of the indices used are schematically shown in Table 2. Density (Urban Density and Agricultural Density) expresses as a percentage the area of a given system over the total territory in a given reference year. The Urban Variation Ratio makes it possible to analyse diachronically the variation of urban areas in a given territory while the urban conversion rate (UCS expressed in $\mathrm{km} 2 / \mathrm{y}$ ) makes it possible to detect the energy of the studied phenomenon. In addition, the extent to which each of the six landscape systems has been affected by land-use transitions was also investigated at national level. For the latter, reference was made to 3 categories: areas with higher biopermeability $\left(\mathrm{ELM}^{*}\right)$, urban areas (U) and agricultural areas (A). For the evaluation of the lost equivalent agricultural production, change layers were used, with reference to two periods (1990-2000 and 2000-2018) and, specifically, the transformations of the AI and EA systems into the $\mathrm{U}$ system defined in Table 1 were considered. For each state, the agricultural land converted for urban purposes was associated with the agricultural yield of wheat in order to obtain the equivalent potential loss (CPL in Table 2) and thus, taking into account the population, also the lost production per capita (LPC in Table 2). It should be noted that the demographic data refers to the entire national territory, while the land consumption data only refers to continental areas. The agricultural yield used is specific to each country and is obtained as the average value of the agricultural yields of national soils cultivated with wheat and refers to the years 1990 to 2018. For the assessment of the economic loss, the average price to the seller for the year 2018 was combined with the Crop Production Potential Loss. In addition, Euro- 
pean countries have been grouped by geographical area, the breakdown of which is shown in Table 3.

Table 2. Main indices used.

\section{Main indexes}

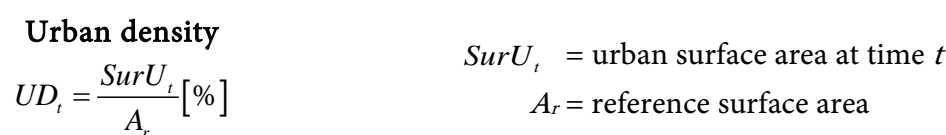

Urban variation ratio

$U V R_{t_{1}-t_{2}}=\frac{\operatorname{Sur} U_{t_{2}}-\operatorname{SurU}_{t_{1}}}{\operatorname{Sur} U_{t_{1}}}[\%] \quad \operatorname{Sur} U_{t}=$ urban surface area at time $t$

Urban conversion speed

$U C S_{t_{1}-t_{2}}=\frac{\operatorname{SurU}_{t_{2}}-\operatorname{SurU}_{t_{1}}}{n}\left[\frac{\mathrm{kmq}}{\text { year }}\right]$

Agriculture density

$$
A D_{t}=\frac{\operatorname{SurA}_{t}}{A_{r}}[\%]
$$

Crop production potential loss

$C P L_{t_{1}-t_{2}}=\Delta \operatorname{Sur}_{A-U} * \bar{Y}_{\text {wheat }}\left[\frac{\text { tonne }}{\text { year }}\right]$

Lost crop production per capita

$L C P_{t_{1}-t_{2}}=\frac{C P L_{t_{1}-t_{2}}}{P o p_{t}}\left[\frac{\text { tonne }}{\text { year } * \text { inhab. }}\right]$
Sur $U_{t}=$ urban surface area at time $t$

$n=$ number of years between $t_{1}$ and $t_{2}$

SurA $A_{t}=$ agriculture surface area at time $t$

$A_{r}=$ reference surface area

$\Delta S u r_{A-U}=$ land take from agriculture areas between $t_{1}$ and $t_{2}$

$\bar{Y}_{\text {wheat }}=$ mean yield for wheat

$C P L_{t_{1}-t_{2}}=$ Crop production potential loss Pop $_{t}=$ inhabitants at time $t$

Table 3. Geographical subdivisions adopted.

\begin{tabular}{|c|c|c|c|c|}
\hline \multicolumn{5}{|c|}{ Countries } \\
\hline \multirow{2}{*}{$\begin{array}{c}\text { Eastern Europe } \\
\text { Bulgaria }\end{array}$} & \multirow{2}{*}{$\begin{array}{c}\text { Western Europe } \\
\text { Austria }\end{array}$} & \multicolumn{2}{|c|}{ Northern Europe Central Europe } & \multirow{2}{*}{$\begin{array}{c}\begin{array}{c}\text { Southern } \\
\text { Europe }\end{array} \\
\text { Bulgaria }\end{array}$} \\
\hline & & Belgium & Austria & \\
\hline Croatia & Belgium & Denmark & Czech Republic & Croatia \\
\hline Czech Republic & Denmark & Estonia & France & Greece \\
\hline Estonia & Finland & Finland & Germany & Italy \\
\hline Hungary & France & Irish Republic & Hungary & Portugal \\
\hline Latvia & Germany & Latvia & Poland & Romania \\
\hline Lithuania & Greece & Lithuania & Slovakia & Spain \\
\hline Poland & Irish Republic & Netherlands & Slovenia & \\
\hline Romania & Italy & Sweden & & \\
\hline Slovakia & Netherlands & United Kingdom & & \\
\hline \multirow[t]{4}{*}{ Slovenia } & Portugal & & & \\
\hline & Spain & & & \\
\hline & Sweden & & & \\
\hline & United Kingdom & & & \\
\hline
\end{tabular}




\section{Result}

Processing the status layers of the CORINE data shows that in 2018, almost half of the European territory was occupied by agricultural areas (27\% IA and 19\% EA), about one third by forests (32\%) and the remainder by semi-natural environments (12\%), water bodies (5\%) and urbanised areas (5\%). Since 1990 the coverage values have followed a negative trend for EA, IA and SN to the benefit of the remaining landscape systems as shown in Table 4.

About $50 \%$ of the exclusively man-made (U) system belongs to four countries: Germany, France, the United Kingdom and Poland; the other 50\% is accounted for by the remaining 21 countries. For the period 2000-2018, the average European urban conversion rate (UCS) was $1790 \mathrm{~km}^{2} / \mathrm{y}$, which means that every year an average area equal to that of the city of London (the third largest European city) has been urbanised, thus reaching $32,200 \mathrm{~km}^{2}$ urbanised in 18 years, an extension equal to that of Belgium and Luxembourg. Looking at Western Europe alone, the conversion rate for the period 2000-2018 was $1376 \mathrm{~km}^{2} / \mathrm{y}$, which is more than twice as high as the corresponding rate for Eastern Europe of 414 $\mathrm{km}^{2} / \mathrm{y}$.

The UD (Urban Density) value for 2018 exceeded the European average (5.03\%) in 13 countries and the highest values, in all chronological sections, were recorded in the countries of north-western Europe with a peak for Belgium, which already in the $1990 \mathrm{~s}$ stood at $20 \%$. On the contrary, as shown in Figure 2, the lowest values were reached by Sweden and Finland. The biggest change is in the Netherlands, which has increased from $10.1 \%$ to $14.7 \%$ in about 30 years. An analysis of the UVR (Urban Variation Ratio) between 2000 and 2018 shows that Spain has increased its urban areas by about 3/5, a trend followed in Eastern Europe by Poland and Latvia. As far as agricultural areas are concerned, it appears that, on average in 2018 , about $45.5 \%$ of the national territories were used for agricultural purposes and the analyses carried out show a progressive although weak annual decrease of $-1.5 \%$ on average. Also in 2018 , as shown in Figure 3, 14 countries had an $\mathrm{AD}$ heat index higher than the European average with more than $50 \%$ of the land used for this purpose, 9 showed an $\mathrm{AD}$ greater

Table 4. Trend of European landscape systems from 1990 to 2018 (for 1990, data for the United Kingdom, Finland and Sweden are not available).

\begin{tabular}{cccccc}
\hline & $\mathbf{1 9 9 0}$ & $\mathbf{2 0 0 0}$ & $\mathbf{2 0 0 6}$ & $\mathbf{2 0 1 2}$ & $\mathbf{2 0 1 8}$ \\
\hline U & 4.34 & 4.27 & 4.65 & 4.97 & 5.03 \\
IA & 32.25 & 26.93 & 27.13 & 26.96 & 26.98 \\
EA & 23.61 & 20.13 & 19.03 & 18.77 & 18.68 \\
F & 26.84 & 31.31 & 31.67 & 32.43 & 32.50 \\
SN & 10.88 & 12.79 & 12.62 & 11.95 & 11.90 \\
W & 2.07 & 4.57 & 4.90 & 4.91 & 4.91 \\
\hline
\end{tabular}




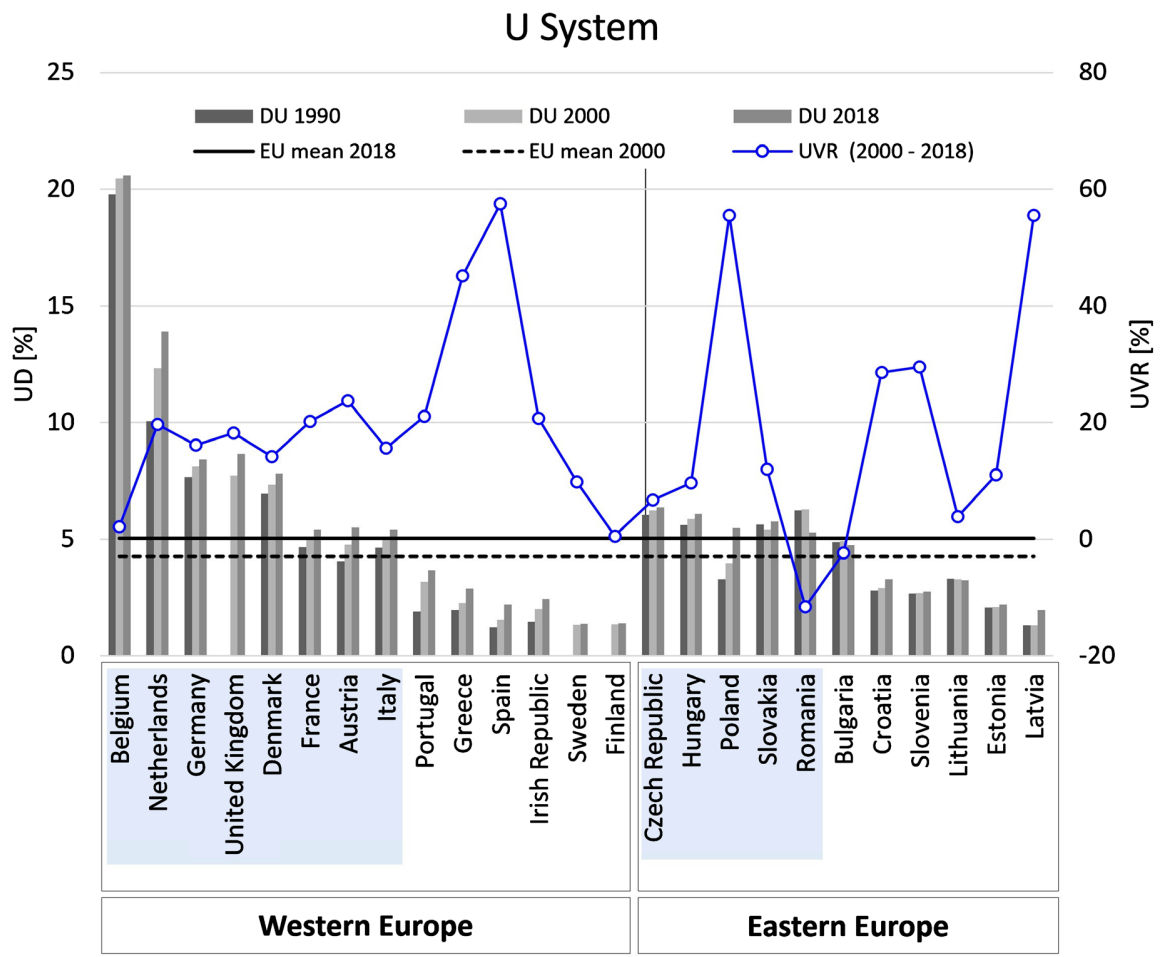

Figure 2. Trend of Urban Landscape Macrosystem in European countries (1990-2018). Urban density (UD) in European countries for 1990, 2000 and 2018 (bars). The horizontal black line represents the European average value for 2000 (dotted line) and for 2018 (continuous line). The countries highlighted in light blue exceed the European 2018 UD.

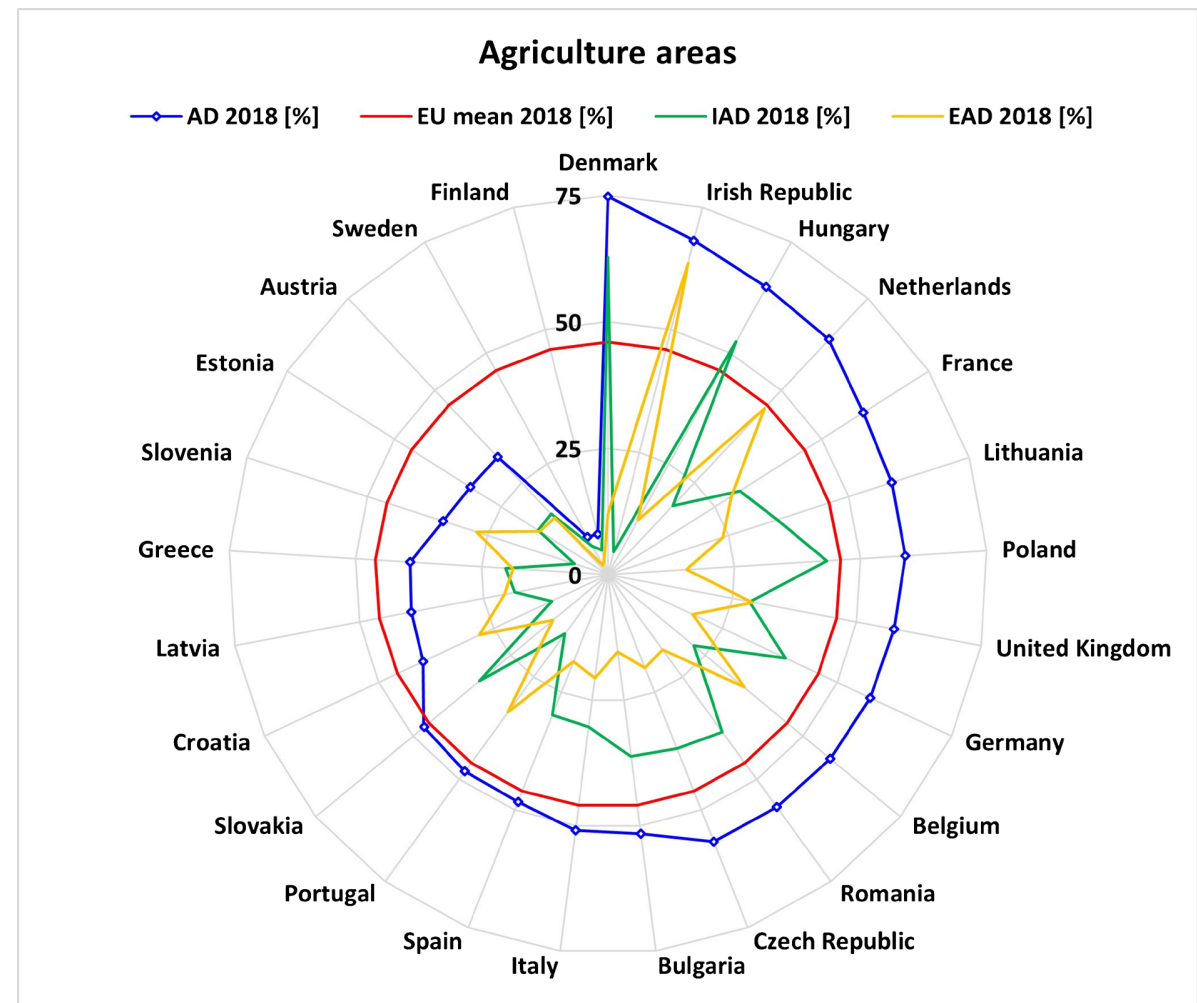

Figure 3. Agricultural cover ratio in European countries. 
than $30 \%$, while the lowest values characterized the Scandinavian (Sweden and Finland) countries where for morphological and climatic reasons $\mathrm{AD}<10 \%$. The results for Ireland and Denmark were interesting, with around two thirds of the latter covered by agricultural land, and although this value was high it was still lower than in 1990 (80\%). Ireland showed a stable AD over time at 68\%, Hungary also showed similar values but lost about 3 percentage points in 30 years. As indicated above, this decreasing trend is common to all the territories considered, even if the values are different: they range from a minimum loss of 25 $\mathrm{km}^{2}$ in 30 years for Bulgaria to a maximum of $17,600 \mathrm{~km}^{2}$ for Poland. In total, almost $75,000 \mathrm{~km}^{2}$ of agricultural land was lost, an area larger than that of BENELUX.

Land use changes between 1990 and 2018 amounted to approximately 30 million hectares. As represented schematically in the Sankey diagram in Figure 4, 26\% of these transformations were in agricultural areas and $72 \%$ in more biopermeable environments. The major transformations are internal to the categories considered, which indicates for example in the case of agricultural land, a change of crop or in the case of urban areas a change of the urban fabric. Generally speaking, transformations outside the identified classes have very low values, but a particular case is represented by the conversion of agricultural areas into urbanised areas, which accounts for $7 \%$ of the total. Urban transformation, as shown in Figure 5, has decreased over time but agricultural areas remain the most affected.

Between 1990 and 2000 about 750,000 ha (corresponding to about $80 \%$ of the total) of the urban areas derived from the transformation of this type of soil, between 2012 and 2018 the contribution decreased to 240,000 ha (about 57\% of the total), while the interclass transformation grows, in fact of the changes to

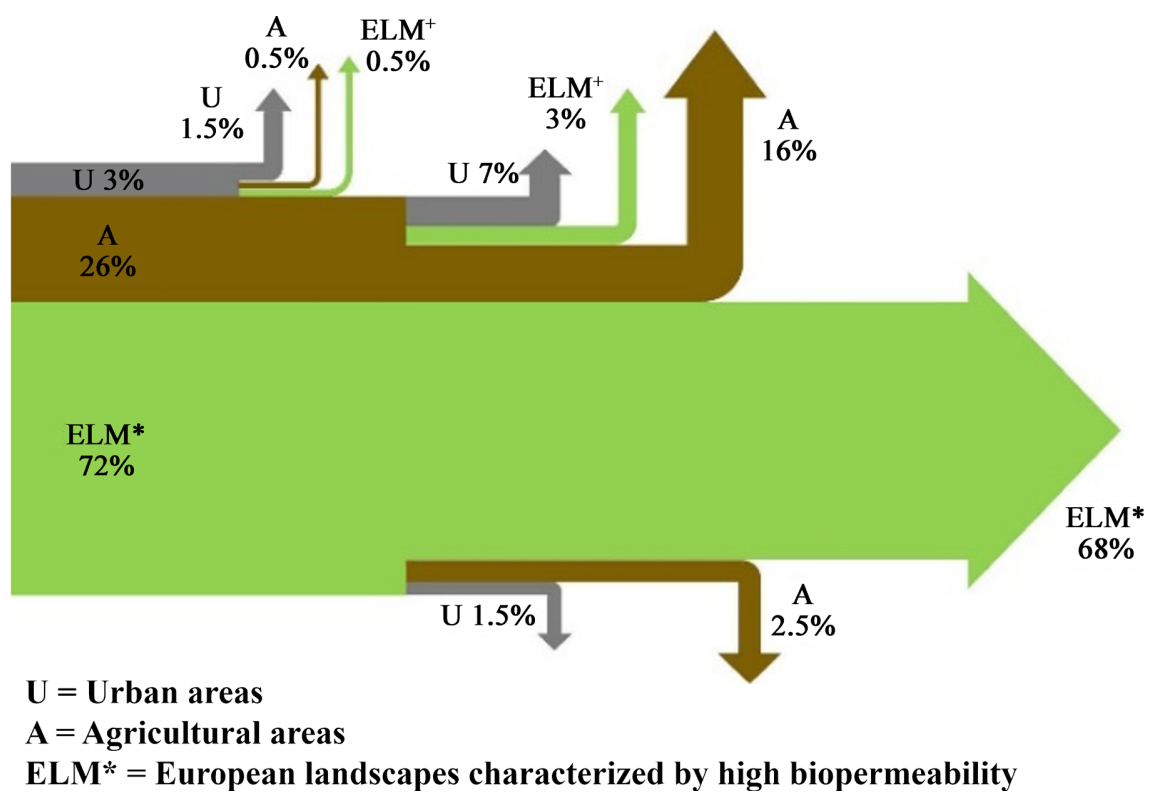

Figure 4. Sankey diagram for Land Use/Land Cover changes analysis (1990-2018). 


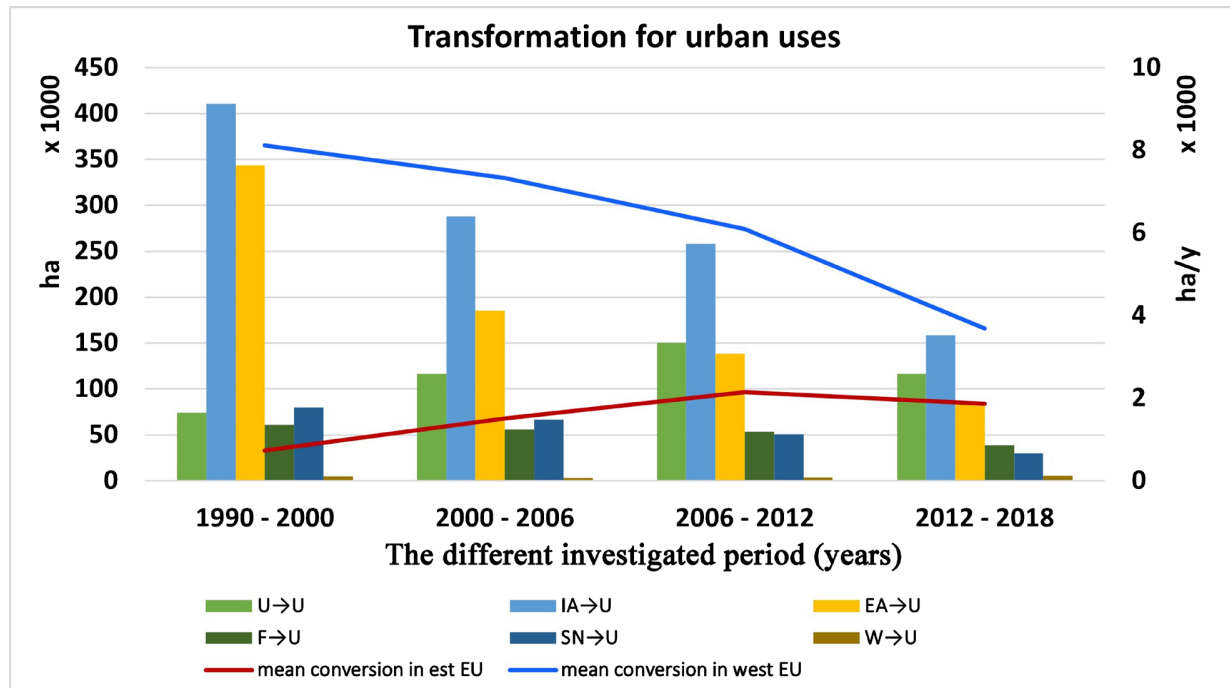

Figure 5. Land-to-Urban conversion matrix (bars) in the two distinct time periods and land uptake rate trends (ha/year) for European land.

urban use in the last investigated period, almost $30 \%$ occurred in this category, a value more than tripled compared to that of the 90 s $(8 \%)$, probably linked to infilling practices. The annual average conversion for the Western European countries showed a decreasing trend, going from over 8100 ha/y (1990-2000) to 3688 ha/y (2012-2018), while for the Eastern countries the trend was first increasing with a maximum of $2144 \mathrm{ha} / \mathrm{y}$ (2006-2012) and then decreasing to $1868 \mathrm{ha} / \mathrm{y}$ (2012-2018). It should be noted that in this case the maximum value reached was in any case lower than the minimum recorded for the Western area. Between 1990 and 2018, urban land conversion in Europe amounted to more than 2 million hectares, $80 \%$ of which involved agricultural land. At the national level, it appears that for $75 \%$ of the countries, more than two thirds of the transformations for urban purposes took place on agricultural soils, which for 14 out of the 25 countries considered, mainly involved category IA soils. The highest values were recorded in Germany, Spain and France with more than 300,000 ha consumed by each. In the case of the Netherlands, land consumption in the period under review amounted to 150,000 ha, of which 145,000 ha was agricultural land. This corresponds to approximately $6 \%$ of the total national agricultural area (reference year 2000), while in the other countries the figure is much lower and is generally below or slightly above one percentage point. Slovenia is the country with the lowest value of 1141 ha, of which less than half was on previously agricultural land. In order to investigate the agricultural loss related to this phenomenon, the CPL (Crop production potential loss) index was introduced. It enables the quantification of agricultural loss with reference to a specific crop, which in the present case is wheat. The value of the agricultural wheat yield for the European Union (EU28), although there have been fluctuations over the years, tends to grow linearly. This is undoubtedly due to the agricultural model aiming at a strong quantitative growth of products with large use of chemicals accompanied 
by technological development applied to both machinery (for all stages from field preparation to harvesting) and seeds (molecular biology, epigenetics...) (Agrawal \& Rakwal, 2012; Springer \& Schmitz, 2017; Scotch et al., 2009; Black \& Bewley, 2000). This trend is generally followed by all Member States, but yields vary according to geo-pedological, climatic, technological and morphological conditions. Specifically, while the European average is $5 \mathrm{t} / \mathrm{ha}$ in 2000 and $5.4 \mathrm{t} / \mathrm{ha}$ in 2018, the 7 countries where the yield is higher than this value are all in northwestern Europe, and in particular in 2018 the highest values were in Ireland (8.4 $\mathrm{t} / \mathrm{ha}$ ), the Netherlands ( $8.6 \mathrm{t} / \mathrm{ha}$ ) and Belgium ( $8.5 \mathrm{t} / \mathrm{ha})$. Assigning to each country the average value of agricultural yields measured from 1990 to 2018, the conversion of agricultural land for urban purposes between the 1990s and 2018 resulted in a loss of potential agricultural production (CPL) of $10 \mathrm{Mt}$ of wheat per year in Europe, 40\% of which due to urban conversions between 1990 and 2000 and the remaining $60 \%$ to those between 2000 and 2018. At the national level, as shown in Figure 6, France and Germany lost more than 2 million tonnes of wheat annually, followed by the Netherlands (1.2 Mt/y) and Spain $(859,000$ $\mathrm{t} / \mathrm{y})$. These 4 countries with $7 \mathrm{Mt} / \mathrm{y}$ together account for 70\% of European CPL. For some states the 1990-2000 figure is not available (UK, Sweden, Finland) and for Latvia there are no conversions of agricultural land to artificial surfaces to be detected. In Germany, the losses associated with the urban conversion of agricultural land in the years 1990-2000 exceeded by almost half a million tonnes per year the CPL associated with the period 2000-2018, which

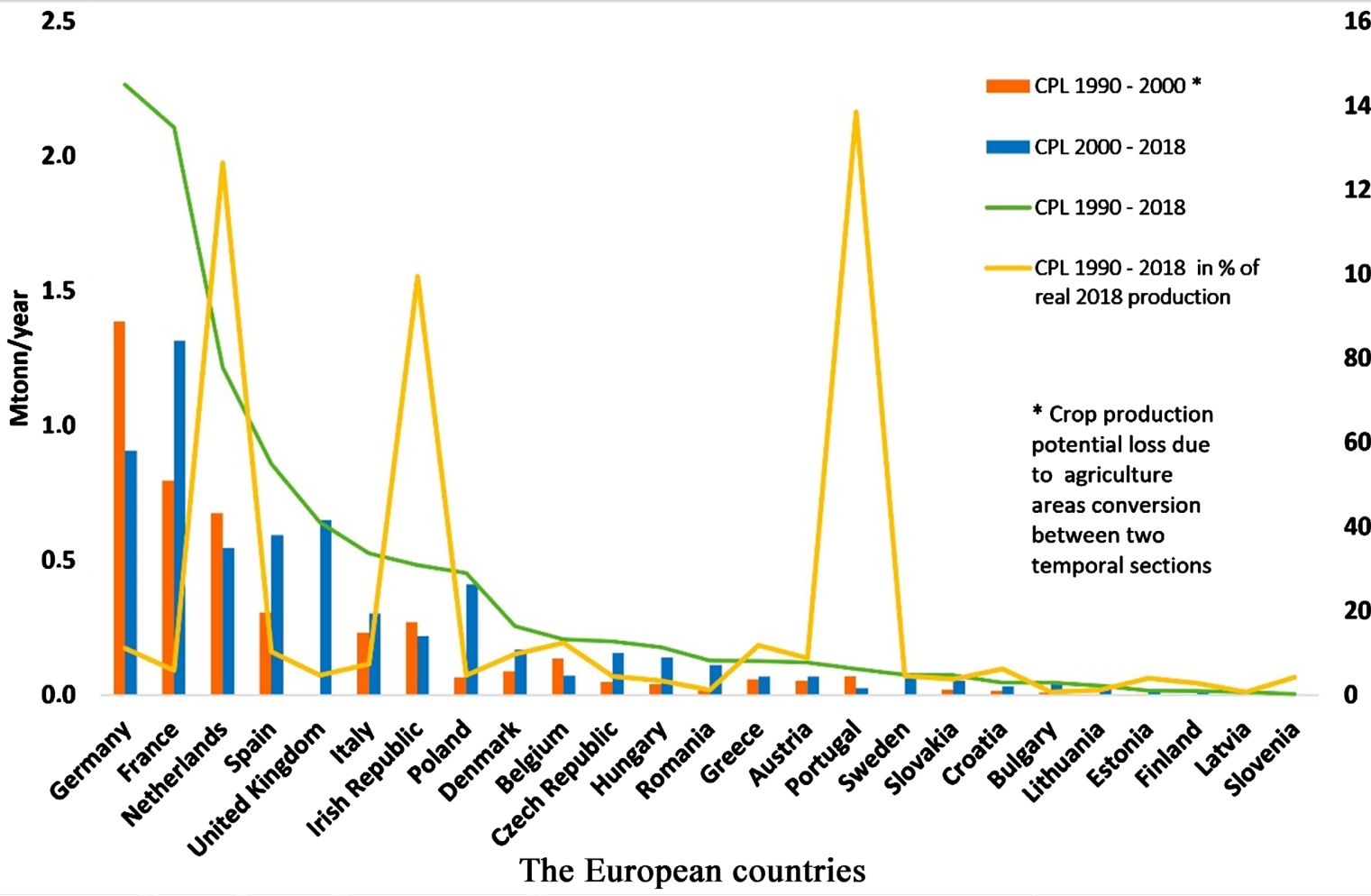

Figure 6. Potential lost agricultural production (CPL) among the time sections. 


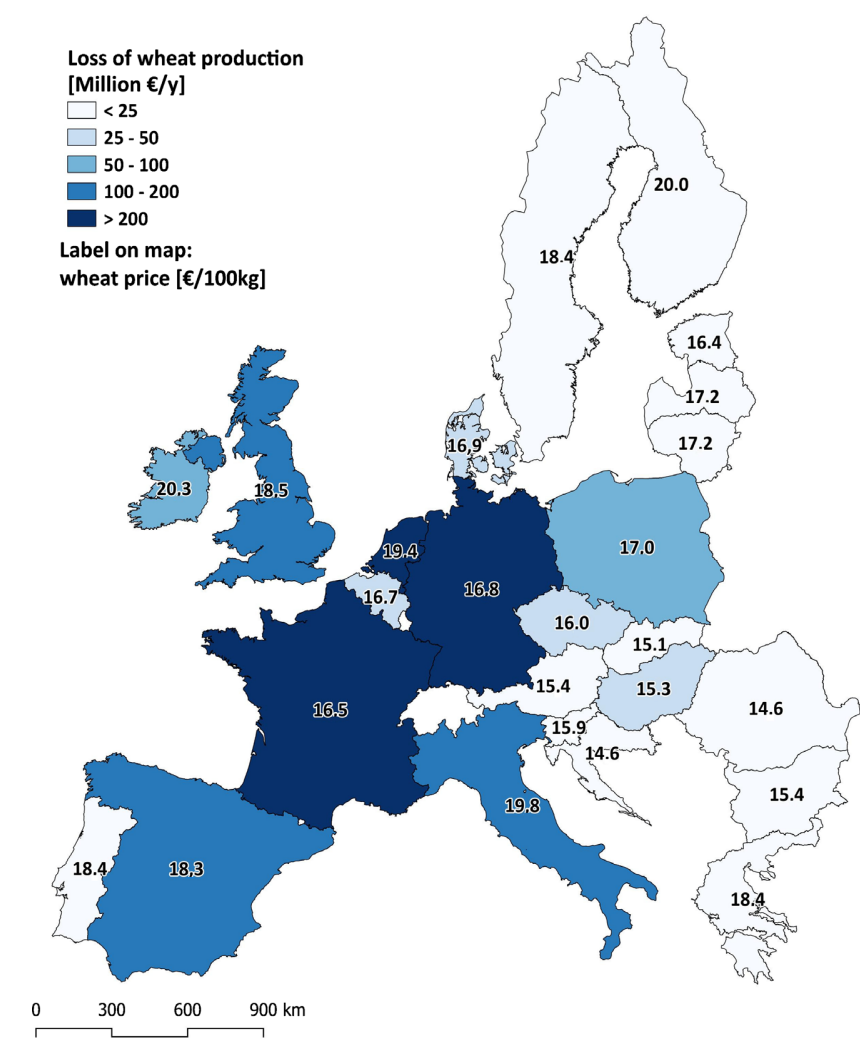

(a) was almost twice as long. Four other countries showed this trend, namely the Netherlands, Ireland, Belgium and Portugal. For Spain, Denmark and Croatia, the CPL 1990-2000 was about half that of the following two decades, although of course with different values (between 1990 and 2000 Spain $=300,000 \mathrm{t} / \mathrm{y}$, Denmark $=87,000 \mathrm{t} / \mathrm{y}$ and Croatia $=10,000 \mathrm{t} / \mathrm{y}$ ). Slovenia had the lowest CPL value, although the variation between the two investigated periods was 10 times greater. Similar trends were observed in other countries such as Poland $(+500 \%)$ and Romania (+400\%). Considering that the average per capita use of wheat for food purposes in Europe is $107 \mathrm{~kg} / \mathrm{y}$, these unproduced quantities would be enough to satisfy the food needs of 66 million Europeans for one year (equivalent to the population of France) and almost 110 million people if the average per capita consumption is considered to be worldwide $(66.6 \mathrm{~kg} / \mathrm{y})$. Every European country imports wheat; if we compare the value of 2019 imports with the CPL we see that the Czech Republic, France, Hungary, Ireland and Slovakia with their potential agricultural production could have more than met their domestic needs without resorting to imports. France, for example, imported 380,000 tonnes of wheat, which is less than $20 \%$ of what is not produced annually as a result of urban conversion of agricultural land. The LPC index measures the potential output lost per capita and the geography of European values is shown in Figure 7(a). Ireland has the highest value at around $100 \mathrm{~kg} / \mathrm{y} /$ inhabitant for transformations between 1990

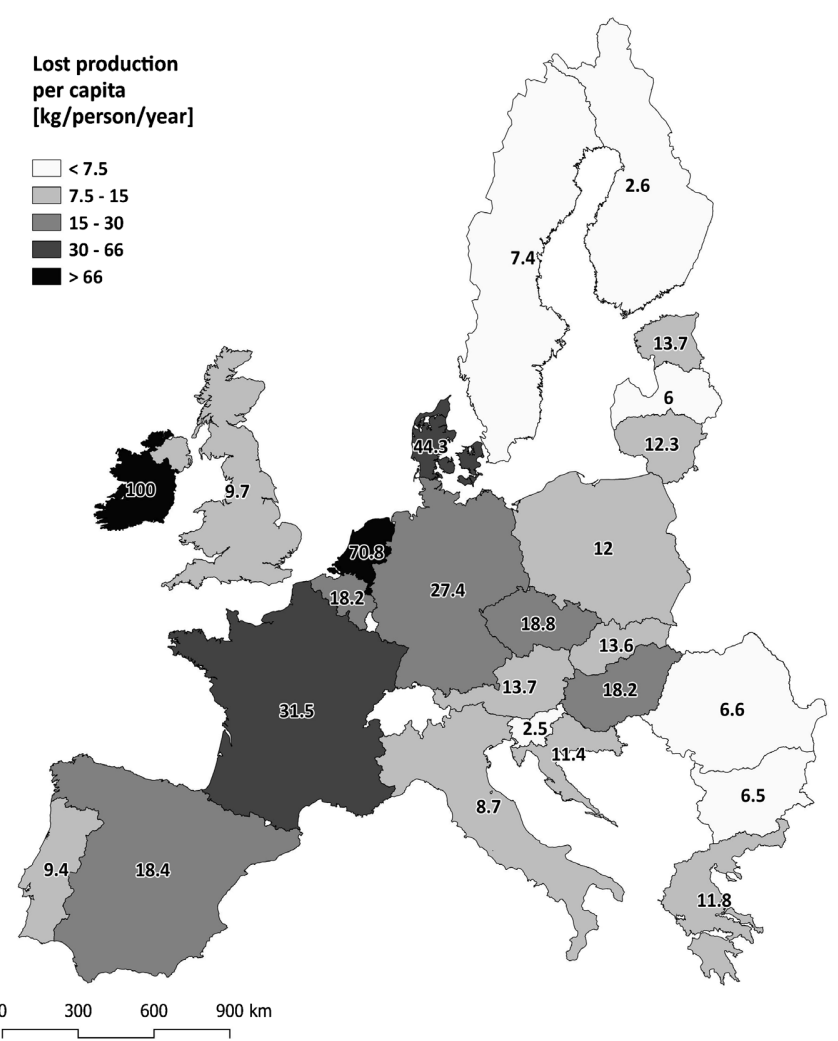

(b)

Figure 7. Agricultural loss due to land consumption in European countries in (a) and (b). 
and 2018, followed by the Netherlands with $70.8 \mathrm{~kg} / \mathrm{y} /$ inhabitant. Both states exceed the world average per capita food requirement of $66.6 \mathrm{~kg} / \mathrm{y} / \mathrm{ab}$ (FAO, 2017). LPCs higher than $30 \mathrm{~kg} / \mathrm{y} / \mathrm{ab}$ are France $(31.5 \mathrm{~kg} / \mathrm{y} / \mathrm{ab})$ and Denmark with $44.3 \mathrm{~kg} / \mathrm{y} / \mathrm{ab}$, which is equal to the per capita annual requirement of a Central American citizen. Still high values of $15-30 \mathrm{~kg} / \mathrm{y} /$ inhabitant are found mainly in Central and Eastern Europe (Germany, Belgium, Czech Republic, Hungary and Spain). Ten countries are in the second range $(7.5-15 \mathrm{~kg} / \mathrm{y} / \mathrm{inh})$, most of them in the east, with Austria and Slovakia having the highest values (around $13 \mathrm{~kg} / \mathrm{y} / \mathrm{inh}$ ). The remaining 6 countries do not exceed $7.5 \mathrm{~kg} / \mathrm{y} / \mathrm{inh}$ abit, all of which are in Eastern Europe and include the Scandinavian countries as well as Latvia, Romania and Bulgaria. The lowest value is recorded in Slovenia (2.5 $\mathrm{kg} / \mathrm{y} /$ inhabitant) followed by Finland $(2.6 \mathrm{~kg} / \mathrm{y} /$ inhabitant $)$. Wheat prices paid to the producer are collected periodically by the Union based on data provided by the individual countries. Here the 2018 data is used as the most recent ones are incomplete. Prices vary from country to country and remain around the European average of $€ 17 / 100 \mathrm{~kg}$, with Romania and Croatia having the lowest price at $€ 14.61 / 100 \mathrm{~kg}$ and Irish producers the highest at $€ 20.3 / 100 \mathrm{~kg}$. National prices and the equivalent lost potential production mean that the loss of revenue, linked to the loss of European agricultural production, amounts to $€ 1.8$ billion per year or $91 \%$ of the value of European agricultural production of durum wheat in 2018 and $8 \%$ of that of wheat and spelt in the same year. The countries in which earnings shortfalls are lowest are mainly located in the East, particularly in the Scandinavian, Baltic and Balkan countries. The lowest loss is in Slovenia with $0.81 \mathrm{M} € / \mathrm{y}$ followed by Latvia $(1.98 \mathrm{M} € / \mathrm{y})$ and Sweden $(2.91 \mathrm{M} € / \mathrm{y})$. The highest losses are estimated for Germany (381 M€/y), France (347 M€/y) and the Netherlands with $236 \mathrm{M} € / \mathrm{y}$, which is $91 \%$ of the Dutch wheat and spelt production in 2018. Significant values are also estimated for Portugal and Ireland, the latter losing around $98 \mathrm{M} € / \mathrm{y}$ equivalent to $101 \%$ of the value of national wheat and spelt production in 2018 .

\section{Discussion}

In Europe, urbanised areas have increased from $4.2 \%$ to $5 \%$ since 2000 , covering a total area of $210,000 \mathrm{~km}^{2}$, an area equal to that of Great Britain. The national UD values in some cases deviate significantly from the European average. This is the case in the Netherlands and Belgium, which reached the highest recorded value $(20.9 \%)$. The evaluation of the UVR showed that variations greater than $50 \%$ occurred in Spain, Poland and Latvia, with some cases showing a negative value, probably due to the technical characteristics of the data. Between 1990 and 2000, the acquisition mode changed from manual photo-interpretation of satellite images to Computer Aided Photo-Interpretation (CAPI) and since 2006, change layers (CHA) have become the main output of CLC. From this reporting year onwards, the status layers were obtained by merging the change layers with the 
status layer of the previous reporting year, in order to maintain the advantages of the higher resolution of the CHAs in the overall data. The use of a higher resolution datum makes it possible to carry out a more accurate identification of the prevailing land use in a given area and therefore, areas that had been ascribed as urban, due to the greater detail have been better identified (Figure 8(a), Figure 8(b)), which justifies the results found.

Furthermore, the methods used for the cartographic acquisition of CLC data (MMU 25 ha and minimum width of linear elements equal to 100 meters) do not make it possible to detect all dispersed settlements (Romano \& Zullo, 2013) present in some of the countries analyzed, such as Italy, Spain, Albania and Greece. Many new settlements (residential or tourist accommodation) have the typical characteristics of sprawl (Egidi et al., 2020; Henning et al., 2015), due to obvious reasons tied to economic return, settlements can be ascribed to the sprinkling model owing to their building density and extremely low coverage ratios (Dutta \& Das, 2019; Urbieta et al., 2019; Saganeiti et al., 2018; Romano et al., 2017). This type of settlement is often developed spontaneously or subject to poor land-use planning control, compounded by the lack of underlying urban planning, making it extremely impactful from the standpoint of landscape, energy, land consumption and management costs (Carruthers \& Ulfarsson, 2003; Manganelli et al., 2020; Thompson, 2013).

The fragmented morphology of the type landscape generates problems in the use of medium-low resolution geographical layers, which, for example, are suitable to capture well-defined urban margins (Figure 9(a)), typical of Northern European cities, but makes them less reliable for analyses where the settlement pattern is highly dispersed (Romano \& Zullo, 2013; Romano et al, 2017). In fact, in these cases both the MMU of 25 ha and that of 5 ha are too high to detect this type of settlements that often have the size of the single building or aggregates of a few units as shown in Figure 9(b). These problems are less evident for other land cover types which, on the contrary, have larger extensions and are more compatible with the CORINE MMU.

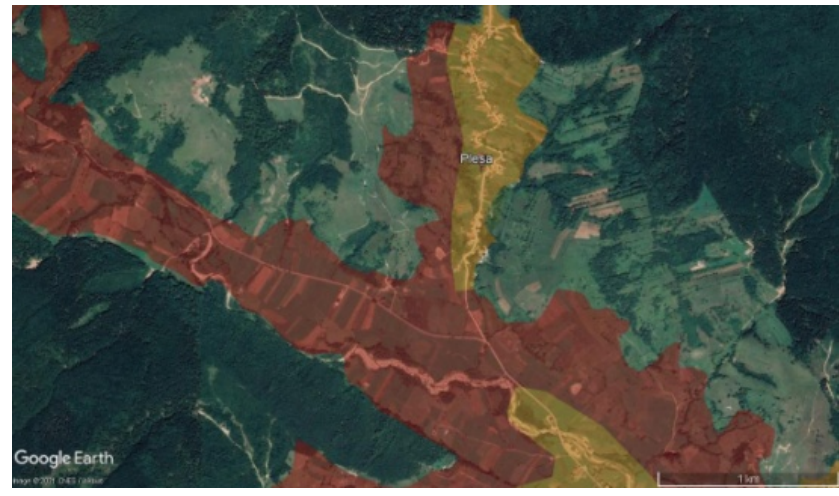

(a)

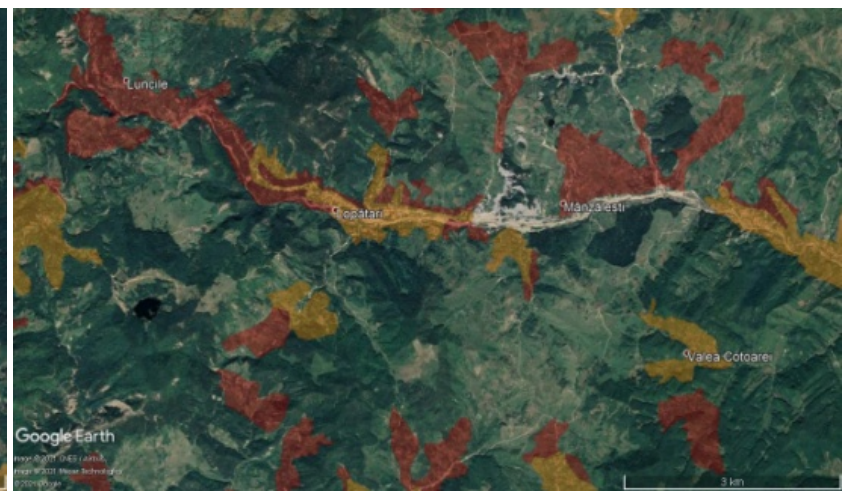

(b)

Figure 8. Comparison of urban areas reported by CLC 2000 (in red) and CLC 2006 (in yellow) with the actual situation in 2006 in Romania in (a) and (b). 


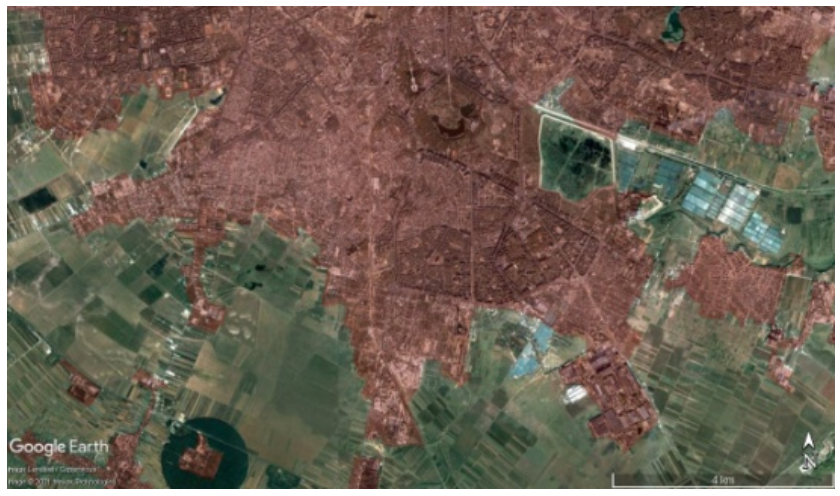

(a)

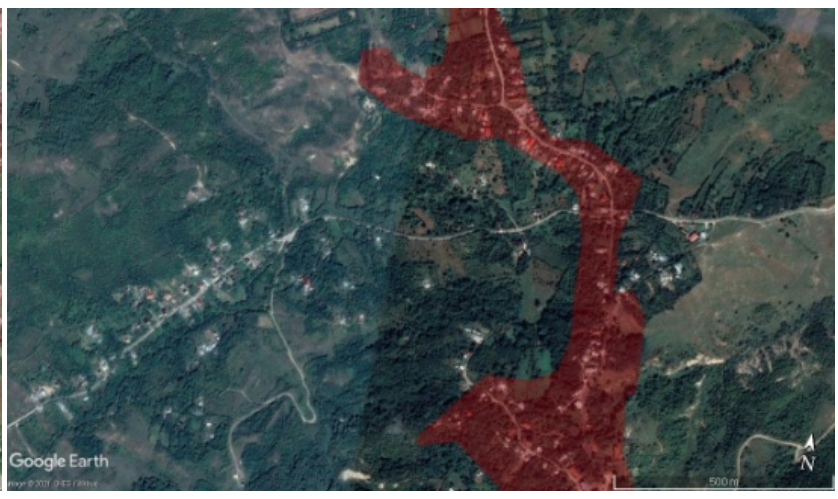

(b)

Figure 9. CLC figure (in red) for compact (a) and dispersed (b) urbanization compared to the actual condition detected by satellite imagery.

\section{Conclusion}

Agricultural soils should first and foremost ensure adequate food supply. However, the development of a model of agriculture, particularly since the 1950s, aimed at strong quantitative growth in low-quality production has generated significant environmental impacts. In addition to the environmental problems directly generated by this unsustainable model, there are also those related to the climate crisis, the emission of air pollutants (Emberson et al., 2003; Schenone \& Lorenzini, 1992), water and soil pollution (Mahmoud \& Ghoneim, 2016; Okoronkwo et al., 2005; Feleafel \& Mirdad, 2013). Bearing in mind the 2030 Agenda's goals on poverty, hunger and achieving health and well-being, the research presented here aims at making a contribution in this direction. Analyses have shown the potential agricultural production lost as a result of urban land conversion in terms of both economic and food needs. To these estimates, we should add, although they are not included in the discussion, the potential losses related to the abandonment of cultivated land. The loss of used agricultural areas is also caused by the abandonment of the countryside, particularly in hill and mountain areas, fuelled by the economic difficulties that have affected agriculture in many areas and for many years. The loss of agricultural soils and their degradation is of growing concern (European Commission, 2012; UN, 2015), exacerbated by climate change that, due to increasingly frequent extreme weather events, is constantly endangering harvests. As already pointed out, what has emerged in this research could underestimate the real extent of the phenomenon, especially in those areas where the landscape is highly fragmented (Italy, Romania, Portugal). Surely the use of higher resolution data would make the analysis more accurate, but at present, although high-resolution data (Urban Atlas) are available, they have an extension limited to some geographical areas. In any case, the study, despite the limitations, clearly shows the effect that urbanization has on the ability of European countries to produce food and also highlights that, although the phenomenon and its extent were known (Gardi et al., 2015), little or nothing has 
been done in concrete terms. The initial institutional enthusiasm that led to the drafting of a proposal for a European directive on soil protection (COM (2006) 232) was followed by several documents that were dense in content (European Commission, 2011; European Commission, 2012; European Commission, 2013) and that inter alia set the goal of zero net land occupation increase by 2050 . However, the level of cogency proved to be very low. The lack of sensitivity shown by the Member States regarding this issue has resulted in an increase in urbanized land of $16,000 \mathrm{~km}^{2}$ between 2006 and 2018 and therefore requires the introduction of stringent regulatory constraints, which have proved effective in other sectors such as energy. The systematic application of de-sealing techniques, currently applied mainly in Western Europe and in particular in Northern Europe, with the restoration of the surface layer of the soil and of all its functions, could certainly contribute both to increasing the amount of land for agricultural use and to curbing the effects of urban soil conversion that this study has highlighted.

\section{Conflicts of Interest}

The authors declare no conflicts of interest regarding the publication of this paper.

\section{References}

Agrawal, G. K., \& Rakwal, R. (Eds.) (2012). Seed Development: OMICS Technologies toward Improvement of Seed Quality and Crop Yield. Springer. https://doi.org/10.1007/978-94-007-4749-4

Agrawal, M. (2005). Effects of Air Pollution on Agriculture: An Issue of National Concern. National Academy. Science Letters (India), 28, 93-106.

Ashraf, M. A., Maah, M. J., Yusoff, I., \& Mehmood, K. (2010). Effects of Polluted Water Irrigation on Environment and Health of People in Jamber, District Kasur, Pakistan. International Journal of Basic \& Applied Sciences, 10, 37-57.

Black, M., \& Bewley, J. D. (Eds.) (2000). Seed Technology and Its Biological Basis. CRC Press.

Bossard, M., Feranec, J., \& Otahel, J. (2000). CORINE Land Cover Technical Guide: Addendum 2000 (Vol. 40). European Environment Agency.

Büttner, G. (2014). CORINE Land Cover and Land Cover Change Products. In I. Manakos, \& M. Braun (Eds.), Land Use and Land Cover Mapping in Europe (pp. 55-74). Springer. https://doi.org/10.1007/978-94-007-7969-3 5

Carruthers, J. I., \& Ulfarsson, G. F. (2003). Urban Sprawl and the Cost of Public Services. Environment and Planning B: Planning and Design, 30, 503-522. https://doi.org/10.1068/b12847

Dutta, I., \& Das, A. (2019). Exploring the Dynamics of Urban Sprawl Using Geo-Spatial Indices: A Study of English Bazar Urban Agglomeration, West Bengal. Applied Geomatics, 11, 259-276. https://doi.org/10.1007/s12518-019-00257-8

EEA (European Economic Area) (2017) Land Take in Europe: Indicator Assessment. https://www.eea.europa.eu/data-and-maps/indicators/land-take-3/assessment

Egidi, G., Cividino, S., Vinci, S., Sateriano, A., \& Salvia, R. (2020). Towards Local Forms of Sprawl: A Brief Reflection on Mediterranean Urbanization. Sustainability, 12, Article 
No. 582. https://doi.org/10.3390/su12020582

Emberson, L., Ashmore, M., \& Murray, F. (2003). Air Pollution Impacts on Crops and Forests: A Global Assessment (Vol. 4). Imperial College Press.

https://doi.org/10.1142/p244

European Commission (2011). Tabella di marcia verso un'Europa efficiente nell'impiego delle risorse. Comunicazione della Commissione al Parlamento Europeo, al Consiglio, al Comitato economico e sociale Europeo e al Comitato delle Regioni. COM (2011), 571.

European Commission (2012). Orientamenti in materia di buone pratiche per limitare, mitigare e compensare l'impermeabilizzazione del suolo. European Commission, 15 (2012), 62.

European Commission (2013). Settimo programma generale di azione dell'Unione in materia ambientale "Vivere bene entro i limiti del nostro pianeta", 2013-2020, Decisione n. 1386/2013/ue del Parlamento europeo e del Consiglio del 20 novembre 2013.

European Commission (2020). Strategia dell'UE sulla biodiversità per il 2030-Riportare la natura nella nostra vita. $\operatorname{COM}(2020) 380$ Final.

Falcucci, A., Maiorano, L., \& Boitani, L. (2007). Changes in Land-Use/Land-Cover Patterns in Italy and Their Implications for Biodiversity Conservation. Landscape Ecology, 22, 617-631. https://doi.org/10.1007/s10980-006-9056-4

Feleafel, M. N., \& Mirdad, Z. M. (2013). Hazard and Effects of Pollution by Lead on Vegetable Crops. Journal of Agricultural and Environmental Ethics, 26, 547-567. https://doi.org/10.1007/s10806-012-9403-1

Foley, J. A., Defries, R., Asner, G. P., Barford, C., Bonan, G., Carpenter, S. R. et al. (2005). Global Consequences of Land Use. Science, 309, 570-574.

https://doi.org/10.1126/science.1111772

Folke, C., Biggs, R., Norström, A. V., Reyers, B., \& Rockström, J. (2016). Social-Ecological Resilience and Biosphere-Based Sustainability Science. Ecology and Society, 21, Article No. 41. https://doi.org/10.5751/ES-08748-210341

Food and Agriculture Organization of the United Nations (FAO) (2017, November). Food Outlook: Biannual Report on Global Food Markets. Food and Agriculture Organization of the United Nations.

Gardi, C., Panagos, P., Van Liedekerke, M., Bosco, C., \& De Brogniez, D. (2015). Land Take and Food Security: Assessment of Land Take on the Agricultural Production in Europe. Journal of Environmental Planning and Management, 58, 898-912. https://doi.org/10.1080/09640568.2014.899490

Henning, E. I., Schwick, C., Soukup, T., Orlitová, E., Kienast, F., \& Jaeger, J. A. G. (2015). Multi-Scale Analysis of Urban Sprawl in Europe: Towards a European de-Sprawling Strategy. Land Use Policy, 49, 483-498. https://doi.org/10.1016/j.landusepol.2015.08.001

Levers, C., Schneider, M., Prishchepov, A. V., Estel, S., \& Kuemmerle, T. (2018). Spatial Variation in Determinants of Agricultural Land Abandonment in Europe. Science of the Total Environment, 644, 95-111. https://doi.org/10.1016/j.scitotenv.2018.06.326

Mahmoud, E. K., \& Ghoneim, A. M. (2016). Effect of Polluted Water on Soil and Plant Contamination by Heavy Metals in El-Mahla El-Kobra, Egypt. Solid Earth, 7, 703-711. https://doi.org/10.5194/se-7-703-2016

Manganelli, B., Murgante, B., \& Saganeiti, L. (2020). The Social Cost of Urban Sprinkling. Sustainability, 12, Article No. 2236. https://doi.org/10.3390/su12062236

Munafò, M. (2021). Consumo di suolo, dinamiche territoriali e servizi ecosistemici. Edizione 2021. Report SNPA 22/21, SNPA. 
Okoronkwo, N. E., Igwe, J. C., \& Onwuchekwa, E. C. (2005). Risk and Health Implications of Polluted Soils for Crop Production. African Journal of Biotechnology, 4, 1521-1524.

Prokop, G., Jobstmann, H., \& Schonbauer, A. (2011). Report on Best Practices for Limiting Soil Sealing and Mitigating Its Effects. European Commission.

Romano, B., \& Zullo, F. (2013). Models of Urban Land Use in Europe: Assessment Tools and Criticalities. International Journal of Agricultural and Environmental Information Systems (IJAEIS), 4, Article No. 5. https://doi.org/10.4018/ijaeis.2013070105

Romano, B., Zullo, F., Fiorini, L., Ciabò, S., \& Marucci, A. (2017). Sprinkling: An Approach to Describe Urbanization Dynamics in Italy. Sustainability, 9, Article No. 97. https://doi.org/10.3390/su9010097

Romano, B., Zullo, F., Marucci, A., \& Fiorini, L. (2018). Vintage Urban Planning in Italy: Land Management with the Tools of the Mid-Twentieth Century. Sustainability, 10, Article No. 4125. https://doi.org/10.3390/su10114125

Ruddock, L., \& Lopes, J. (2006). The Construction Sector and Economic Development: The "Bon Curve". Construction Management and Economics, 24, 717-723. https://doi.org/10.1080/01446190500435218

Saganeiti, L., Favale, A., Pilogallo, A., Scorza, F., \& Murgante, B. (2018). Assessing Urban Fragmentation at Regional Scale Using Sprinkling Indexes. Sustainability, 10, Article No. 3274. https://doi.org/10.3390/su10093274

Schenone, G., \& Lorenzini, G. (1992). Effects of Regional Air Pollution on Crops in Italy. Agriculture, Ecosystems \& Environment, 38, 51-59. https://doi.org/10.1016/0167-8809(92)90166-9

Scotch, M., Odofin, L., \& Rabinowitz, P. (2009). Linkages between Animal and Human Health Sentinel Data. BMC Veterinary Research, 5, Article No. 15. https://doi.org/10.1186/1746-6148-5-15

Springer, N. M., \& Schmitz, R. J. (2017). Exploiting Induced and Natural Epigenetic Variation for Crop Improvement. Nature Reviews Genetics, 18, 563-575. https://doi.org/10.1038/nrg.2017.45

Thompson, D. (2013). Suburban Sprawl: Exposing Hidden Costs, Identifying Innovations. Smart Prosperity Institute.

UN (2015). Transforming Our World: The 2030 Agenda for Sustainable Development. https://sdgs.un.org/2030agenda

Urbieta, P., Fernandez, E., Ramos, L., Martínez, G. M., \& Bento, R. (2019). A Land-Cover Based Urban Dispersion Indicator Suitable for Highly Dispersed, Discontinuously Artificialized Territories: The Case of Continental Portugal. Land Use Policy, 85, 92-103. https://doi.org/10.1016/j.landusepol.2019.03.048

Zanfi, F. (2013). The Città Abusiva in Contemporary Southern Italy: Illegal Building and Prospects for Change. Urban Studies, 50, 3428-3445. https://doi.org/10.1177/0042098013484542 